\title{
Health care to immigrant and Portuguese pregnant women in Portugal
}

\author{
CUIDADOS DE SAÚDE A GESTANTES IMIGRANTES E PORTUGUESAS EM PORTUGAL \\ CUIDADO DE LA SALUD A MUJERES EMBARAZADAS IMIGRANTES Y PORTUGUESAS \\ EN PORTUGAL
}

\section{Emília de Carvalho Coutinho', Alcione Leite da Silva ${ }^{2}$, Carlos Manuel Figueiredo Pereira ${ }^{3}$, Alexandra Isabel Almeidaa $^{4}$, Paula Alexandra Batista Nelas ${ }^{5}$, Vitória Barros Castro Parreira ${ }^{6}$, Maria Odete Amaral ${ }^{7}$}

\begin{abstract}
This study aimed to assess the care received and the barriers faced by immigrants and Portuguese pregnant women in Portugal. This is an exploratory qualitative study, resorting to applying semi-structured interviews to 60 immigrant and 22 Portuguese women. Content analysis supported by QSR Nvivo10 program was used. The study was approved by an Ethics Committee. The results showed four categories related to affective dimensions-relational, cognitive, technical-instrumental and health care policy for pregnant women. As for the barriers in health care, these were mentioned by some of the expectant mothers, especially immigrant women. Almost all, both immigrant and Portuguese, pregnant women were satisfied with the health care.
\end{abstract}

\section{DESCRIPTORS}

Pregnancy

Health care

Portuguese health system

\section{RESUMO}

Este estudo teve como objetivo conhecer os cuidados de saúde recebidos e as barreiras enfrentadas por gestantes imigrantes e portuguesas, em Portugal. Trata-se de um estudo de natureza qualitativa, do tipo exploratório, com aplicação de entrevista semiestruturada a 60 mulheres imigrantes e 22 portuguesas. Foi utilizada a análise de conteúdo apoiada pelo programa QSR Nvivo10. O estudo foi aprovado por uma Comissão de Ética. Os resultados apontaram quatro categorias relacionadas às dimensões afetivo-relacional, cognitiva, técnico-instrumental e política do cuidado de saúde à gestante. Já as barreiras nos cuidados de saúde foram mencionadas por algumas gestantes, com destaque para as imigrantes. Na sua grande maioria, tanto as gestantes imigrantes quanto as portuguesas, encontravam-se satisfeitas com os cuidados de saúde.

\section{DESCRITORES \\ Gestação \\ Cuidados de saúde \\ Sistema de saúde português}

\section{RESUMEN}

Este estudio tuvo como objetivo evaluar la asistencia sanitaria recibida y las barreras que enfrentan las madres inmigrantes y portuguesas en Portugal. Se trata de un estudio cualitativo, exploratorio, con entrevista semiestructurada que se aplicó a 60 mujeres inmigrantes y 22 portuguesas. Se utilizó el análisis de contenido apoyado por el programa QSR Nvivo10. El estudio fue aprobado por un Comité de Ética. Los resultados mostraron cuatro categorías: las relacionadas con las dimensiones afectivas y relacionales, con la política, la técnica instrumental y el cuidado de la salud cognitiva de las embarazadas. Se han mencionado las barreras en el cuidado de la salud por algunas embarazadas, sobre todo inmigrantes. La gran mayoría de las mujeres embarazadas tanto inmigrantes como portuguesas, se encontraban satisfechas con la atención de la salud.

\section{DESCRIPTORES \\ Embarazo \\ Cuidado de la salud \\ Sistema de salud portugués}

${ }^{1}$ PhD in Nursing Sciences, School of Health of Viseu IPV/CIDETS, Viseu, Portugal. ${ }^{2}$ PhD in Philosophy and Nursing, Department of Health Sciences/ University of Aveiro, Aveiro, Portugal. ${ }^{3} \mathrm{PhD}$ in Human Biology School of Health of Viseu IPV/CIDETS, Viseu, Portugal. ${ }^{4}$ Nurse, currently unafilliated, Viseu, Portugal. ${ }^{5} \mathrm{PhD}$ in Education Sciences, School of Health of Viseu IPV/CIDETS, Viseu, Portugal. ${ }^{6}$ Master in Nursing Sciences, School of Nursing of Porto, Porto, Portugal. ${ }^{7} \mathrm{PhD}$ in Public Health, School of Health of Viseu IPV/CIDETS, Viseu, Portugal. 


\section{INTRODUCTION}

Becoming a mother is a phenomenon experienced by women, from any part of the world, characterized by a mix of emotions, new challenges and physical and psychological changes, among others, assuming both positive and negative meanings ${ }^{(1)}$.

Motherhood is considered a transition, defined as "the shift from one stage of life, condition, or status to another" $(2,3)$. Immigration is also another transition phenomenon experienced by foreign women. This occurrence is more and more frequently motivated by the search for better living conditions or emotional reasons (to go live with the spouse). Portugal is a country where immigration occurs $^{(4)}$, thus justifying the importance of cultural care, which combines cultural diversity and universality to nursing care, resulting in a culturally congruent care ${ }^{(5)}$.

Currently, due to social changes, the knowledge that once was generational and culturally transmitted, is now sought after, by resorting increasingly to the care of health professionals, especially nurses as facilitators of the transition to motherhood ${ }^{(6)}$. Nursing encompasses the art and science of facilitating the transition to health and well-being of the population and has as its central "mission" to facilitate the transition processes across the life cycle ${ }^{(3)}$.

The Portuguese health care services, offered to pregnant women, are established by the National Health Policy, and include the promotion and restoration of health and prevention of disease, during pregnancy, which begin in the preconception period ${ }^{(7)}$.

In this sense, it is expected that nurses assume, increasingly, their frontline role in antenatal surveillance, so that the parturient and the newborn are healthy ${ }^{(8)}$, thereby reducing maternal and perinatal mortality ${ }^{(9)}$. Prenatal care, focusing on pregnant women and their life context, may influence the experience of motherhood with greater autonomy and health(10).

Therefore, it is necessary to be aware of barriers that may hinder access of this woman to health care. These barriers may be related to factors connected to pregnancy or health institutions, as for example the resources, the quality of care and the health policies adopted ${ }^{(9)}$.In this sense, health protection is perceived not only as a right but as a joint responsibility of citizens, society and state, with the freedom in the search and delivery of care ${ }^{(11)}$. In this sense, the Constitution of the Portuguese Republic is a facilitator of access to maternal health care, since it determines the gratuity of the health system during this period, among others rights directed to the woman/couple, the parturient, puerpera, and new born ${ }^{(12)}$.

Given the above, this study aims to identify the health care received and the barriers faced by immigrant and Portuguese pregnant women in Portugal.

\section{METHODS}

This is a qualitative, exploratory, descriptive study. A total of 82 women, 60 immigrant and 22 Portuguese (Table 1), belonging to two groupings of health centres of two districts of the Central Region of Portugal, participated in the study. The nationalities of the mothers were: Portuguese $(n=22)$, Brazilian $(n=14)$, Ukrainian $(n=11)$, Chinese $(n=8)$, Moldova $(n=4)$, African $(n=4)$, and French and Russian ( $n=3$ each), and thirteen other nationalities (Congolese, Dutch, Cape Verdean, Guineans, Argentinian, Byelorussian, Polish, Romanian, Ethiopian, Canadian, Senegalese and Switzerland) ( $n=1$ for each). Inclusion criteria were; to be Portuguese or Immigrant; to have been a mother for less than a year; to understand the Portuguese language, to agree to participate in the study.

Table 1 - Socio-demographic characterization of the sample

\begin{tabular}{|c|c|c|c|}
\hline & $\begin{array}{c}\text { Portuguese } \\
\mathrm{N}=\mathbf{2 2} \\
\end{array}$ & $\begin{array}{c}\text { Immigrant } \\
\mathrm{N}=60\end{array}$ & $\begin{array}{r}\text { Total } \\
\mathrm{N}=82 \\
\end{array}$ \\
\hline \multicolumn{4}{|l|}{ Age Group } \\
\hline$<21$ & 0 & 1 & 11 \\
\hline $21-35$ & 18 & 43 & 61 \\
\hline$>35$ & 4 & 16 & 20 \\
\hline \multicolumn{4}{|l|}{ Marital Status } \\
\hline Married/de facto union & 20 & 49 & 69 \\
\hline Single/divorced/widow & 2 & 11 & 13 \\
\hline \multicolumn{4}{|l|}{ Academic Qualifications } \\
\hline$\leq 9^{\circ}$ grade & 6 & 13 & 19 \\
\hline 10-12 grades & 3 & 17 & 20 \\
\hline Higher Education & 13 & 30 & 43 \\
\hline \multicolumn{4}{|l|}{ Professional Status } \\
\hline Employed & 19 & 44 & 63 \\
\hline Unemployed & 3 & 16 & 19 \\
\hline \multicolumn{4}{|l|}{ Pregnancy Monitoring } \\
\hline Monitored & 20 & 41 & 61 \\
\hline Not monitored & 2 & 19 & 21 \\
\hline \multicolumn{4}{|l|}{ No. of births } \\
\hline 1 birth & 13 & 22 & 35 \\
\hline 2 births & 8 & 21 & 29 \\
\hline 3 or more births & 1 & 17 & 18 \\
\hline \multicolumn{4}{|l|}{ No.-deliveries } \\
\hline 1 delivery & 13 & 29 & 42 \\
\hline 2 deliveries & 8 & 20 & 28 \\
\hline 3 or more deliveries & 1 & 11 & 12 \\
\hline
\end{tabular}

Data collection was conducted between February 2011 and February 2012, through semi-structured interviews, a weekly average of 1.5 interviews. The guiding instrument consisted of socio-demographic characterization and of seven or eight open questions (depending on the participant be Portuguese or immigrant, respectively), in order to get the data in the speech of the informants themselves. The interviews took place at the Health Centres involved, with varied duration 45-125 minutes with a mean of 70 minutes.
Health care to immigrant and Portuguese pregnant women in Portugal

Coutinho EC, Silva AL, Pereira CMF, Almeida Al, Nelas PAB,

Parreira VBC, Amaral MO 
Data analysis was based on the Technique of Categorical Content Analysis ${ }^{(13)}$, with the support of the program Qualitative Analyses Software Certified Partner (QSR NVivo version 10). Similar ideas were systematized, proceeding to the coding of the registration units (RU) and respective categorization.

This study was approved by the ethics committees of the Health Centres involved in the study. The script of the interview was previously submitted to and approved by the National Commission for Data Protection $(\mathrm{Ca}-$ se $85 / 2011$, No. 191/2011). The data confidentiality and anonymity of participants were guaranteed. The informed consent for the interview and recording of verbatim was obtained after full information about the study. To maintain anonymity, each participant was identified by two letters of the alphabet, followed by their nationality (e.g. DC Ukraine).

\section{RESULTS}

The results of the analysis and coding of the verbatim of Portuguese and immigrant pregnant women correspond to health care during pregnancy and the barriers faced during this phase of their lives.

Health care during pregnancy encompassed, from the perspective of immigrant and Portuguese participants, four categories on the affective-relational, cognitive, technical-instrumental and care policy dimensions, as can be seen in Table 2.

Table 2 - Dimensions of health care during pregnancy

\begin{tabular}{ll}
\hline Affective- & Trust relation \\
relational & Support \\
dimension & Attention \\
& Interest \\
& To know they could rely on health professionals \\
\hline Cognitive & Nutrition \\
dimension & Weight \\
Health education & Physical Activity \\
sessions & Rest \\
& Risk behaviour \\
& Travels \\
& Blood pressure \\
& Sexuality \\
& How to access information \\
& Delivery preparation \\
& Care of the baby \\
& Breast feeding preparation \\
& Nutrition \\
& Stretch Marks Prevention \\
& Physical Activity \\
Safe environment & Avoid efforts \\
& Dialog with the baby \\
& To keep informed about the pregnancy \\
& To attend to prenatal consultations \\
\hline &
\end{tabular}

Continued...
...Continuation

\begin{tabular}{ll}
\hline $\begin{array}{l}\text { Technical- } \\
\text { instrumental } \\
\text { dimension }\end{array}$ & Blood pressure evaluation \\
Technical & Weight evaluation \\
procedures & Undertaking Blood tests \\
& Cardiound examinations at least every three month \\
& Guided tour to the maternity \\
\hline Political & Gratuity in care including surveillance tests and \\
Dimension & vaccines; \\
Rights of pregnant & Right to be absent from work to attend the \\
women & appointments; \\
& Get medical leave when necessary; \\
& Dentist Check; \\
& Discount on medicines; \\
& Subsidies and allowances prenatal \\
& Priorities in public places. \\
\hline
\end{tabular}

The affective-relational dimension was related to the relationship of trust established between health professionals from the areas of medicine and nursing and pregnant women, to open dialog, the support, interest and attention received from these professionals during pregnancy, and to know that they could count on them in any situation. All were unanimous in pointing out that this dimension of care was very significant for them, mainly because they feel vulnerable and insecure with this new condition. For immigrants, this dimension was vital for being away from their home country and their support network. The testimonials below exemplify this dimension of care.
"I felt a lot of support [by professionals] and this gives us the will to repeat the experience. It meant a lot and is effec- tive at a time when we are vulnerable; it really is important care and support" (AN France).
"As I had already lost two children, I had more support from them (...) from the health centre ... They explained calmly, I felt safe "(BU Ukraine).

\begin{abstract}
"Were very friendly, from pregnancy to childbirth, both medical and nurse were very nice and thoughtful in everything" (BP Brazil).

"A support, at the time I had no father and mother, and now she [the nurse] replaces them a bit ... Then the nurse replaces them those important moments ... I could talk to her about everything, it was important for me"(AQ Portugal).
\end{abstract}

In the cognitive dimension were included the education sessions for health related guidelines received during pregnancy and the methods used. The themes highlighted by pregnant women were nutrition and weight, physical activity and rest, risk behaviors, travel, blood pressure, sexual activity, how to access the information, preparation for childbirth and baby care (weight, growth, clothing, preparation for breastfeeding. guidelines received helped them feel more informed, calm, confident and better prepared.

"I think it's very good, they use very good methods to provide the information; I took flyers home in every consultation, they explained everything, if I did not realize they [the 
nurse and the doctor] explained. I could call out of hours at home ... Alcohol, tobacco, sexual activity, weight, growth of the baby, clothing, preparation for breastfeeding, the nurse was all, and all consultations we would-be talking about some topics that are there" (BC Brazil).

"The nurse spoke of nutritional care" (AA Portugal).

"With preparation for childbirth, I was very restful in childbirth" (BX Belarus).

"Yes the nurse was present in consultations, I love the nurse. There was a stage when I got here, I was already desperate, did not sleep and she calmed me down and explained to me what to do ... I felt safer, more prepared, I had forgotten many things as how to treat a child" (UZ Ukraine).

Based on the guidance received, and Portuguese immigrant pregnant women reported having applied the knowledge gained in caring for themselves and the baby, taking care of nutrition, hydration and prevention of stretch marks, physical exercises, frequenting safe environments, avoiding efforts, talking to baby, trying to keep themselves informed about pregnancy and attend prenatal consultations.

"Yes, all they [doctors and nurses] said and advised I put everything into practice" (BU Ukraine).

"Had care with nutrition" (AR Brazil).

"I took care in hydrating the body because of subsequent stretch marks" (CG Portugal).

"I exercised, which I already had a habit of doing" (BQ Moldova).

"Avoid smoky environments, nights out" (AP Switzerland).

"I had been informed by professionals that talking to the baby, soothed the child and so I did that" (BK Portugal).

The technical-instrumental dimension of care included the evaluation of blood pressure and weight, blood tests, ultrasounds at least every three months, cardiotocographic record and visit to maternity ward, as can be seen from the statements below:

"I also did blood tests" (AL China).

"I did the morphological ultrasound" (AW Brazil).

"I weighed myself in all consultations" (AM China).

"I did cardiotocographic registration" (BY Poland).

"It was late in pregnancy that I went to the maternity hospital" (BH Portugal).).

The political dimension was related to the rights of pregnant women, during pregnancy, according to the Portuguese Constitution. The testimonies of the women, this dimension integrated the gratuity of the monitoring care including tests and vaccines; the right to be absent from work to attend the appointments; obtain medical leave when necessary; dentist check; discount on medicines; subsidies and prenatal allowance; and priorities in public places. Some immigrants valued the gratuity of the Portuguese health care, during pregnancy, and wove comparisons with their countries of origin.

"Here in Portugal I received, free of charge, the dentist checks, medical and nursing consultations, tests, at the health centre" (DC Ukraine).

"I had benefits in terms of exemption in terms of medication" (CB Ethiopia).

"Il had the right to] receive from Social Security an allowance for high risk pregnancy ... I had the right to pre-natal allowance" (CO France).

"Concerning the rights, I booked the consultations outside of working hours and when I could not book off schedule I used that time" (BL Portugal).

"In Ukrainian law it is written that to health everyone has access to, and it is free, but in fact that is not so; Here truly if it is being said it is free, it really is" (DC Ukraine).

Health care, described above, occurred mostly in the public health system. However a minority of pregnant women, mostly Portuguese, had some experience in the private health sector. The reasons given for the choice of the public system were: gratuity; better pregnancy surveillance; specialized care; surveillance shared between health centre and hospital.

"I was being followed in the private system but ... but for financial reasons I opted for the public" (CO France).

"I was followed at the health centre and at the hospital because I had high blood pressure during pregnancy and so I had consultations with a cardiologist" (BG Portugal).

It was very important [to have the monitoring of health professionals] because everything needed I cleared my doubts, I came here more quickly [Health Centre], I felt assurance (BU Ukraine).

"I was going to have the child in the hospital, I had to have consultations from the six months, had to have three consultations and these appointments were there, for them to have knowledge of the case and then follow it, along with the health centre (BH Portugal).

The reasons that lead the minority of pregnant women to opt for private health system, were the result of dislike or be unable to secure a family doctor in the public health system; receive personalized and continuous care; and feel safe.

"I was without a family doctor; they were taking a long time to arrange appointments so I changed to a private" (AP Switzerland).

"I trusted the doctor and thus my reason to go to C. for consultations" (BM Portugal).
Health care to immigrant and Portuguese pregnant women in Portugal

Coutinho EC, Silva AL, Pereira CMF, Almeida Al, Nelas PAB,

Parreira VBC, Amaral MO 
"People do not bind to patients, doctors, and if we want this service, more personalized, maybe we have to opt for other options, paying for it in the private sector" (CM Portugal).

The majority of Portuguese and immigrant pregnant women were satisfied with health care; this satisfaction resulted, largely, of the care of health professionals. However, a minority of pregnant women, particularly immigrant, reported barriers in health care.

\section{Barriers in health care during pregnancy}

Emerging barriers were reported by 22 pregnant women (18 immigrant and 4 Portuguese) and were related to the long waiting time to be attended to ( 6 immigrants and 1 Portuguese); lack of pregnancy supervision at home (3 immigrants and 1 Portuguese); the lack of monitoring by a specialist ( 3 immigrants and 1 Portuguese); long wait to access consultations at the health centre ( 2 immigrants and 1 Portuguese); the lack of monitoring by the same physician ( 3 immigrants); the lack of organization in the health centre and hospital ( 1 immigrant). When they refer these barriers, many immigrants wove comparisons with their countries of origin.

"It took a long time waiting for appointments and I did not
expect that to happen" (BM Portugal).

"It would be nice to have in Portugal monitoring at home by the physician, as we have in Ukraine (Ukraine AC).

"I expected to have a midwife. In Canada, the midwife does everything, they accompany a lot and there is a relationship between them and the mother before and after delivery (AY Canada).

"It took me six weeks to get an appointment at the health centre" (CD Netherlands).

"There should be a little more support, such as the visit of a doctor or nurse to the house to see how a person is, I am not talking only of pregnancy, but postpartum" (AQ Portugal).

"When I was in the health centre the doctor was never the same, changing from one to another" (AB France).

"In terms of organization of the health service, it could greatly improve" (BS Russia).

\section{DISCUSSION}

From the data analysis four categories, affective and relational, cognitive, technical-instrumental and policies emerged, the first three being adopted from a referential|(14), which was used in another study ${ }^{(15)}$. In this sense, the affective-relational dimension refers to Being, resulting from the interactions that allow humans involved in the care, to express their subjectivities related to their experiences. The cognitive dimension relates to the Knowing, ie professional competence, which in this study was shared with the pregnant women, instigating the care of themselves and the baby. The technical-instrumental dimension consists in Doing with quality and competence through specialized technical interventions, permeated by know-how" ${ }^{\prime \prime}(14,15)$. The policies dimension refers to social and health rights enjoyed by people, in this particular case, the pregnant women, due to social and health adopted policies in a given country. All dimensions were important for the pregnant women. Studies with pregnant women based on this framework were not found in the literature.

For pregnant women, in general, the affective-relational dimension was considered important at this stage of their lives. This dimension of health care helped them feel welcomed, supported, feeling welcome to open dialogue, and ultimately to the establishment of a trust. It was directly linked to the way of Being of the health professionals, especially for the nurses, with whom they had most contact. Thus, they expressed satisfaction with the health professionals and therefore to the quality of health care. The results obtained in this dimension are consistent with those presented by a study in which women presented themselves satisfied with the quality of care, claiming attention, respect and punctuality in assistance from the professionals ${ }^{(16)}$. "The experiences of people with the care provided to them are determined primarily by how they are treated when they are experiencing a problem and seek help from health services"(16). They wish to be seen by someone they can "trust and that will receive them promptly in an appropriate environment, with respect and confidentiality"(17). Establishing a relationship of trust with the health professionals is therefore one of the factors that contributes to the tranquility of women during pregnancy, preparing them for childbirth. To provide a good reception is an essential factor for a higher quality of care and consequent satisfaction ${ }^{(16,17)}$. To provide comfort is also to respect the privacy of the pregnant woman, who thus feels safe and respected by the health professionals.

The cognitive dimension has proved vital in health care. The pregnant woman, by virtue of her condition, is more susceptible to the need for the care that is essentially based on learning what is pregnancy, its implications and conditions ${ }^{(10)}$. The role of the nurse starts in the prenatal period, through consultations and health education sessions, addressing the needs and condition of the pregnancy, in which are included, among others, screening for complications, guidance about the period that she is going through, concerning the discomforts typical of pregnancy and relief techniques, the care about nutrition, weight gain, sexuality, the emotional aspects, the risk associated with the use of drugs and not prescribed medication ${ }^{(8)}$.

"In the permanent search for excellence in professional practice, the nurse helps customers achieve maximum health potential" through the "use of opportunities to promote healthy lifestyles" providing "information to generate cog- 
nitive learning and new skills by the customer"(12). In maternal health, this learning is done in the consultations and sessions of health education. For the pregnant women in this study, the education sessions focused on several key issues, which are expressed in the self-care and the baby's care. This knowledge acquired by the woman about the gestational process and preparation for childbirth contribute to reduce anxiety, fear and pain, so characteristic of childbirth $^{(8,18)}$. The preparation facilitates interaction with the pregnant woman and the family ${ }^{(8)}$, thus reflecting its importance. The value attributed by pregnant woman, of this study, to the childbirth preparation was evident in their statements, of feeling more informed and therefore more peaceful and confident, because they are better prepared.

The technical-instrumental dimension encompassed specialized technical interventions, which ranged from high blood pressure and weighing until the conducting exams needed to assess the health of pregnant women. This assessment enables early diagnosis in case of problems and therefore an appropriate intervention, creating tranquility in the pregnant women, family and health professionals, with positive outcomes for the mother-baby pair.

The policies dimension focused on the rights of pregnant women living in Portugal. According to the Constitution of the Portuguese Republic, pregnant woman and new mothers are exempt from user fees and in the Portuguese public health system, all care underlying this state can be use free of charge ${ }^{(19)}$. In addition, rights include dispensation of night work, maternity leave and paternity leave for consultations and breastfeeding, the allocation of subsidies among others rights ${ }^{(20)}$. Pregnant women reported having enjoyed a set of rights, which favored them in this stage of life.

The consultations of the participants were carried out in the public system. However, a small number of pregnant women, with a predominance of Portuguese nationality, used temporarily the private health sector. The reasons stated for the consultations in the public health system were: a gratuity in exams, better surveillance of pregnancy, offering specialized care and shared surveillance between health centre and hospital. In turn, the fact that they did not get a family doctor in the public health system, received more personalized care and felt greater security, were aspects that led some pregnant women to seek the private health system. Pregnant women who opted for the public health system, were satisfied with the health care received.

The vast majority of Portuguese and immigrant pregnant women, were satisfied with health care. The satisfaction of pregnant women is important as these are more likely to demonstrate better self-care and have better outcomes ${ }^{(21)}$. The satisfaction is directly related to the quality of services that a particular institution provides; consequently health services must move towards the preferences and values of their consumers, since their view is a quality indicator ${ }^{(8)}$.
However, several pregnant women showed themselves dissatisfied with some aspects of health care received, particularly for immigrants. These aspects, while barriers to health care, encompassed the difficult access to appointments, problems in professional monitoring at the health centre and the lack of pregnancy monitoring at home. The literature shows that dissatisfaction is usually related to the delay time of an appointment or admission, the waiting results of clinical tests, poor and inadequate information, especially those relating to matters of interest to the client ${ }^{(23)}$.

\section{CONCLUSION}

This study aimed to assess the health care received and the barriers faced by immigrant and Portuguese pregnant women in Portugal. The results indicated four dimensions of health care on the affective-relational, cognitive, technical-instrumental and policy dimensions. The affective-relational dimension involved the relationship of trust between health professionals and pregnant women, open dialogue, support, interest, comfort, good hospitality and attention received from these professionals during pregnancy, and know that they could rely on them in any situation. The cognitive dimension resulted from education sessions for health-related diet and weight, physical activity and rest, risk behaviors, travel, blood pressure, sexual activity, how to access the information, preparation for childbirth and baby care. This cognitive learning was present in caring for themselves and the baby, by the pregnant woman. In technical-instrumental dimension emerged to assess blood pressure and weight, blood tests, ultrasounds, cardiotocographic record and visit to maternity hospital/ward. The policy dimension integrated in the gratuity of monitoring care including examinations and vaccinations; the right to be absent from work to attend the appointments; obtain medical leave when necessary; dentist check; discount on medicines; subsidies and prenatal allowance; and priorities in public places.

The satisfaction displayed by most participants, both by Portuguese and immigrant women, resulted from the health care responding to their health needs. For many immigrants, this care exceeded their expectations, by comparing them with those of their own countries, with emphasis on the gratuity of such care.

However, several pregnant women pointed barriers in healthcare, with a predominance of immigrants. These barriers were: the long waiting time to be consulted; lack of pregnancy monitoring at home; the lack of monitoring by a specialist; long waiting time to access consultations at the health centre; the lack of monitoring by the same physician; and the lack of organization in the health centre and hospital.

The largest number of immigrant pregnant women in relation to the Portuguese; the focus on health care
Health care to immigrant and Portuguese pregnant women in Portugal

Coutinho EC, Silva AL, Pereira CMF, Almeida Al, Nelas PAB,

Parreira VBC, Amaral MO 
in the public system, which prevented a comparison between them and the private system; the fact that no studies were found in the literature focused on the dimensions of health care during pregnancy, preventing further discussion on the same, can be signaled as limitations of this study.

Based on this study, we suggest that others on this subject can be developed with immigrant and Portuguese pregnant women of both public and private systems of care as well as families and health professionals.

\section{REFERENCES}

1. Shimizu H, Lima M. As dimensões do cuidado pré-natal na consulta de enfermagem [The dimensions of the prenatal care in nursing consultation]. Revista brasileira de enfermagem. 2009;62:387-92.

2. Chick N, Meleis Al. Transitions: a nursing concern. In: Chinn $\mathrm{PL}$, publishers. Nursing research methodology. Boulder, CO: Aspen Publication; 1986. p. 237-57.

3. Meleis Al. Transitions Theory. Middle range and situation specific theories in nursing research and practice. New York: Springer Publishing Company; 2010.

4. Instituto Nacional de Estatistica, SP. (Producer). Estimativas anuais de imigração de 2012 [Annual estimates of immigration of 2012]. Anual-INE. (consultado em 10 de outubro de 2013). Disponível em: http://www.ine.pt/xportal/ $x$ main? $x$ pid=INE\&xpgid=ine_indicadores\&indOcorrCod=0006 058\&contexto=bd\&selTab=tab2.

5. Lopes JR, Santos MC, Matos MSD, Ribeiro OP. Multiculturalidade: perspectivas da enfermagem - contributos para melhor cuidar [Multiculturalism: perspectives of nursing - contributions to better care]. Loures: Lusociência; 2009.

6. Graça LCC, Figueiredo MCB, Carreira MTC. Contributos da intervenção de enfermagem de cuidados de saúde primários para a transição para a maternidade [Contributions from the nursing intervention of primary health care for the transition to motherhood]. Rev Enferm Referência 2011; (3): 27-35.

7. Akkerman D, Cleland L, Croft G, Eskuchen K, Heim C, Levine $A$, et al. Routine prenatal care. Bloomington, $\mathrm{MN}$ : Institute for Clinical Systems Improvement; 2012. Available from: https://www.icsi.org/_asset/13n9y4/Prenatal.pdf

8. Marque FC, Dias LMV, Azevedo L. A percepção da equipe de enfermagem [The perception of nursing staff ]. Esc Anna Nery R Enferm. 2006;10(3): 439 - 47.

9. Coutinho EC, Parreira MVBC. Outra forma de olhar de olhar a mãe imigrante numa situação de transição [Another way to look at the immigrant mother in a transition situation]. Millenium 2011; 40: 83-97.
We hope that this study may contribute to improving health care for immigrant and Portuguese pregnant women in Portugal.

\section{ACKNOWLEDGMENT}

Portuguese Foundation for Science and Technology, through project PEst-OE/CED/UI4016/2014, and Centro de Estudos em Educação Tecnologia e Saúde (CI\&DETS).

10. Sercekus P, Mete S. Effects of antenatal education on maternal prenatal and postpartum adaptation. J Adv Nurs. 2010; 66(5): 999-1010.

11. Portugal. História do Serviço Nacional de Saúde. Saiba como nasceu o Serviço Nacional de Saúde e quais os desenvolvimentos dos últimos 30 anos [History of the national health service. Learn how the National Health Service was born and which developments of the last 30 years]. Portal do Cidadão: Ministério da Saúde; 2010. (consultado em Agosto de 2012). Disponível em: http://www.portugal.gov.pt/pt/os-ministerios/ministerio-da-saude/quero-saber-mais/quero-aprender/historia-sns.aspx

12. Ordem Enfermeiros. Regulamento dos padrões de qualidade dos cuidados especializados em enfermagem de saúde materna, obstétrica e ginecológica [Regulation of quality standards of specialized care in nursing of maternal health, gynecologic and obstetric care]. Lisboa: OE; 2011. 1-16. (consultado em agosto 2013). Disponível em: http://www. ordemenfermeiros.pt/colegios/Documents/PQCEESaudeMaternaObstetricaGinecologica.pdf.

13. Bardin L. Análise de Conteúdo [Content analysis]. Lisboa: Edições 70; 2013.

14. Silva AL. O cuidado no encontro de quem cuida e de quem é cuidado [The care in the meeting of who cares and who is careful]. In: Mercado FJ, Gastaldo D, Calderón C. Paradigmas y diseños de la investigación cualitativa en salud: una antologia iberoamericana [Paradigm and qualitative research designs in health: an ibero-American anthology]. Mexico: Universidad de Guadalajara; 2002. p. 285-318.

15. Sousa CSO, Silva AL. HIV/AIDS care according to the perspective of healthcare providers. Rev Esc Enferm USP. 2013; 47(4): 907-14.

16. Queiroz MVO, Jorge MSB, Marques JF, Cavalcante AM, Moreira KAP. Indicators of quality of care at birth based on satisfaction of recent mothers. Texto Contexto Enferm. 2007; 16(3): 479-87. 
17. World Health Organization. The world health report 2008: primary health care now more than ever. Geneva, Switzerland; 2008. (cited 2009 Nov 30). Available from: http:// www.who.int/whr/2008/whr08 en.pdf

18. Yenal K, Sevil Ü. The effects of web-based childbirth education program on activities of daily living of pregnant women. HealthMed. 2012; 6 (7):930-8.

19. Portugal. Decreto-lei n.173 de 1 de agosto de 2003. Dispõe sobre o regime das taxas moderadoras no acesso à prestação de cuidados de saúde no âmbito do Sistema Nacional de Saúde [Rules on the system of charges in access to health care under the National Health System]. Diário da República, Lisboa, 1 de agosto de 2003. Série I-A, p. 4537.
20. Portugal. Direito dos pais [Right of parents]. Portal do cidadão (Producer), 6 de janeiro de 2014 (citado em 6 de janeiro de 2014). Disponivel em: https://www.portaldocidadao.pt/PORTAL/pt/Dossiers/DOS_5+++direitos+dos+pais. htm?passo=3

21. Peterson WE, Charles C, DiCenso A, Sword W. The Newcastle Satisfaction with Nursing Scales: a valid measure of maternal satisfaction with inpatient postpartum nursing care. J Adv Nurs. 2005; 52(6): 672-81. 